\title{
Durable Goods, Inter-Sectoral Linkages and Monetary Policy*
}

\author{
Hafedh Bouakez ${ }^{\dagger} \quad$ Emanuela Cardia ${ }^{\ddagger} \quad$ Francisco J. Ruge-Murcia ${ }^{\S}$
}

First draft: April 2008

This copy: August 2008

\begin{abstract}
Barsky, House and Kimball (2007) show that introducing durable goods into a sticky-price model leads to negative sectoral comovement of production following a monetary policy shock and, under certain conditions, to aggregate neutrality. These results appear to undermine sticky-price models. In this paper, we show that these results are not robust to two prominent and realistic features of the data, namely input-output interactions and limited mobility of productive inputs. When extended to allow for both features, the sticky-price model with durable goods delivers implications in line with VAR evidence on the effects of monetary policy shocks.
\end{abstract}

JEL classification: E21, E23, E31, E52

Keywords: durability, input-output interactions, roundabout production, sectoral comovement, monetary policy

\footnotetext{
${ }^{*}$ We thank the Social Sciences and Humanities Research Council of Canada for financial support. Correspondence: Hafedh Bouakez, HEC Montréal, 3000 chemin de la Côte-Sainte-Catherine, Montréal (Québec), Canada H3T 2A7, E-mail: hafedh.bouakez@hec.ca.

${ }^{\dagger}$ Institute of Applied Economics and CIRPÉE, HEC Montréal.

${ }^{\ddagger}$ Département de sciences économiques and CIREQ, Université de Montréal.

${ }^{\S}$ Département de sciences économiques and CIREQ, Université de Montréal.
} 


\section{Introduction}

In a recent and provocative paper in the American Economic Review, Barsky, House and Kimball (2007) show that, under broad conditions, extending the standard sticky-price model to incorporate durable goods leads to perverse economic implications. In the case where only durable good prices are rigid, the whole economy behaves as if characterized by price stickiness despite the fact that this sector is relatively small. In addition, the correlation of sectoral outputs following a monetary policy shock is basically zero. In the more empirically plausible case where durable good prices are flexible, ${ }^{1}$ monetary shocks have essentially no effect on aggregate output, and induce a negative output comovement across sectors. Since durability is an intrinsic characteristic of many goods in the economy, these results pose a challenge to the large literature that generates money nonneutrality on the basis of sticky prices, and which implicitly assumes that sectoral outputs are (highly) positively correlated so that it is possible to study the aggregate effects of monetary shocks by focusing on a symmetric equilibrium where this correlation is 1 by construction.

This paper shows that both the aggregate neutrality and negative sectoral comovement in Barsky et al. are not robust to incorporating two prominent and realistic features of the data, namely input-output interactions and limited mobility of productive inputs. ${ }^{2}$ Thus, durable goods do not necessarily undermine sticky price models. In order make this point in the simplest possible manner, we construct a parsimonious generalization of Barsky et al.'s model, adopting most of their assumptions and differing only in the two features mentioned above. We model input-output interactions using a roundabout productive structure, and for simplicity, focus on limited labor mobility, rather than capital mobility, across sectors. Since Barsky et al.'s model is a special case of ours, we first replicate their findings and then show, both theoretically and quantitatively, why their results do not survive the generalization proposed here. ${ }^{3}$

Input-output interactions are empirically important: Dale Jorgenson's data on input expenditures by U.S. industries shows that materials (including energy) account for roughly 50 percent of outlays, while labor and capital account for 34 and 16 percent, respectively. ${ }^{4}$ The Use Table of

\footnotetext{
${ }^{1}$ In earlier work (Bouakez, Cardia and Ruge-Murcia, 2005), we construct and estimate a six-sector DSGE model of the U.S. economy. While the null hypothesis of price flexibility can be rejected for nondurable manufacturing and services, it cannot be rejected for agriculture, mining, construction and durable manufacturing.

${ }^{2}$ Barsky et al. point out that their aggregate-neutrality result is fragile and holds only in special circumstances. For example, it vanishes if labor can flow across sectors but the marginal product of labor in the durables sector is not constant (see p. 991). The negative sectoral comovement, however, appears to be robust.

${ }^{3}$ In related work, Carlstrom and Fuerst (2006) show that it may be possible to generate positive sectoral comovement following a monetary policy shock in a model with nominal wage stickiness and firm-level adjustment costs in durable production.

${ }^{4}$ The data set is described in detail in Jorgenson and Stiroh (2000) and is publicly available at http://post.economics.harvard.edu/faculty/jorgenson/data.
} 
the Input-Output (I-O) accounts compiled by the Bureau of Labor Statistics (BLS) shows that 70 percent of the material-input expenditures by the durables sector goes into goods produced by the nondurables sector (see Table 1). The converse proportion is around 10 percent, which is much smaller but still not negligible. More generally, the U.S. I-O matrix is far from being the perfectly diagonal matrix that is implicitly assumed in models without inter-sectoral linkages.

Similarly, the data suggests that labor and capital are not perfectly mobile across sectors. Davis and Haltiwanger (2001) find limited labor mobility across sectors in response to monetary and oil shocks. The differences in real wages between the durables and nondurables sectors reported in Figure 1 suggest that perfect labor mobility, with its implication that wages are the same in all sectors, is an imperfect characterization of the sectoral data. ${ }^{5}$ Households and firms do not appear to completely arbitrage away sectoral wage differentials, perhaps because workers have sector-specific skills and retraining is costly. Regarding capital, Ramey and Shapiro (2001) find in their case study of aerospace plant closings that transferring equipment to another sector is costly and that a large discount is required to entice buyers from outside the sector.

The paper is organized as follows. Section 2 constructs a general sticky-price model with durable goods. The manner in which input-output interactions and imperfect labor mobility are modeled follows closely our previous work on monetary multi-sector models (see Bouakez, Cardia and Ruge-Murcia, 2005). Section 3 describes the calibration. Section 4 reports the quantitative implications of the model and some of its restricted versions, including one that corresponds to the benchmark case in Barsky et al. (2007). This Section also reports the results of sensitivity analysis. Finally, Section 5 concludes.

\section{The Model}

The economy is populated by a constant number of identical, infinitely-lived households, continua of firms in two sectors that respectively produce differentiated durable and nondurable goods, and a government.

\section{$2.1 \quad$ Households}

The representative household derives utility from the consumption of nondurable goods and from the service flow of durable goods, and incurs disutility from hours worked. Following the literature, the service flow of durable goods is assumed to be proportional to the stock and, without loss of generality, the coefficient of proportionality is normalized to 1 . Let $C_{t}^{n}$ and $D_{t}$ respectively denote

\footnotetext{
${ }^{5}$ The raw data for this Figure are average weekly earnings of production workers by sector available from the BLS Web site (www.bls.gov).
} 
the household's nondurable consumption and stock of durables, and let $N_{t}$ denote hours worked. At time $\tau$, the household maximizes

$$
E_{\tau} \sum_{t=\tau}^{\infty} \beta^{t-\tau}\left(U\left(C_{t}^{n}, D_{t}\right)-V\left(N_{t}\right)\right),
$$

where $\beta \in(0,1)$ is the subjective discount rate and $U(\cdot)$ and $V(\cdot)$ are functions that satisfy standard properties and will be specified below in Section 3. The stock of durable goods evolves according to

$$
D_{t}=(1-\delta) D_{t-1}+C_{t}^{d}
$$

where $\delta \in(0,1)$ is the depreciation rate and $C_{t}^{d}$ denotes newly purchased durables. The quantities $C_{t}^{n}$ and $C_{t}^{d}$ are aggregates of varieties produced in the nondurables and durables sector, respectively. In particular,

$$
C_{t}^{j}=\left(\int_{0}^{1}\left(c_{t}^{l j}\right)^{(\epsilon-1) / \epsilon} d l\right)^{\epsilon /(\epsilon-1)},
$$

for $j=n, d$, with $c_{t}^{l j}$ being the household's consumption of the good produced by firm $l$ in sector $j$, and $\epsilon>1$. The variable $N_{t}$ is an aggregate of hours worked in the two sectors

$$
N_{t}=\left(\sum_{j=n, d}\left(N_{t}^{j}\right)^{(\varsigma+1) / \varsigma}\right)^{\varsigma /(\varsigma+1)}
$$

where $N_{t}^{j}=\int_{0}^{1} n_{t}^{l j} d l, n_{t}^{l j}$ is the number of hours worked in firm $l$ in sector $j$ at time $t$, and $\varsigma>0$. The aggregator (3) represents the idea that labor is imperfectly mobile between sectors and, consequently, wages and hours worked in different sectors will not be the same. This aggregator is a tractable way to model the heterogeneity in sectoral labor variables observed in the data, while preserving the representative-household setup. ${ }^{6}$ As we argue below, the qualitative results of this paper are robust to using other modeling strategies to represent limited labor mobility across sectors. Finally, the case of perfect labor mobility assumed by Barsky et al. corresponds to the situation where $\varsigma$ tends to infinity.

The household enters period $t$ with a stock of private one-period nominal bonds $\left(B_{t-1}\right)$, a stock of nominal money balances $\left(M_{t-1}\right)$, and a fixed stock of capital $(K)$. During the period, the household receives wages, rentals, and dividends paid by firms, a lump-sum transfer $\left(T_{t}\right)$ from the government, and interest payments on bonds holdings. These resources are used to purchase

\footnotetext{
${ }^{6}$ On the other hand, notice that labor is perfectly mobile within each sector so that wages and hours worked in different firms of the same sector will be same. The assumption that the cross-sectional dispersion of wages and hours is larger between, than within, sectors is in line with empirical evidence reported by Davis and Haltiwanger (1991).
} 
durable and nondurable goods and to acquire assets to be carried out to next period. Then, the household's budget constraint (in nominal terms) is

$$
\sum_{j=n, d} P_{t}^{j} C_{t}^{j}+B_{t}+M_{t}=\sum_{j=n, d} W_{t}^{j} N_{t}^{j}+R_{t} K+\Pi_{t}+\left(1+i_{t-1}\right) B_{t-1}+M_{t-1}+T_{t}
$$

where $P_{t}^{j}$ is the price index in sector $j, W_{t}^{j}$ is the nominal hourly wage paid by firms in sector $j, R_{t}$ is the rental rate of capital, and $\Pi_{t}=\sum_{j=n, d} \int_{0}^{1} \pi_{t}^{l j} d l$ are dividends with $\pi_{t}^{l j}$ denoting the dividends received from firm $l$ in sector $j$.

The first-order conditions associated with the optimal choice of $C_{t}^{n}, C_{t}^{d}, D_{t}$, and $N_{t}^{j}$ are

$$
\begin{aligned}
U_{1}\left(C_{t}^{n}, D_{t}\right) & =\lambda_{t} P_{t}^{n} \\
\lambda_{t} P_{t}^{d} & =\gamma_{t} \\
U_{2}\left(C_{t}^{n}, D_{t}\right) & =\gamma_{t}-\beta(1-\delta) E_{t} \gamma_{t+1}, \\
V^{\prime}\left(N_{t}\right) \frac{\partial N_{t}}{\partial N_{t}^{j}} & =\lambda_{t} W_{t}^{j}
\end{aligned}
$$

where $\gamma_{t}$ and $\lambda_{t}$ are, respectively, the Lagrange multiplier associated with the constraints (2) and (4), $U_{x}$ denotes the partial derivative of the function $U(\cdot)$ with respect to its $x^{\text {th }}$ argument and $V^{\prime}$ denotes the derivative of $V(\cdot)$ with respect to $N_{t}$. It is easy to show that the consumption demand for the good produced by firm $l$ in sector $j$ is

$$
c_{t}^{l j}=\left(\frac{P_{t}^{l j}}{P_{t}^{j}}\right)^{-\epsilon} C_{t}^{j},
$$

where $P_{t}^{l j}$ is the price set by firm $l$ in sector $j$. As in Barsky et al. (2007), money demand is assumed to be proportional to nominal output, which is formally defined in Section 2.4.

\section{$2.2 \quad$ Firms}

The monopolistically competitive firm $l$ in sector $j$ produces output $y_{t}^{l j}$ using the technology

$$
y_{t}^{l j}=F\left(k_{t}^{l j}, n_{t}^{l j}, h_{t}^{l j}\right)
$$

where $k_{t}^{l j}$ is capital, $h_{t}^{l j}$ is material inputs, and $F(\cdot)$ is a production function with constant returns to scale. Material inputs are combined according to

$$
h_{t}^{l j}=\prod_{i=n, d} \zeta_{i j}^{-\zeta_{i j}}\left(h_{i, t}^{l j}\right)^{\zeta_{i j}},
$$


where $h_{i, t}^{l j}=\left(\int_{0}^{1}\left(h_{m i, t}^{l j}\right)^{(\epsilon-1) / \epsilon} d m\right)^{\epsilon /(\epsilon-1)}, h_{m i, t}^{l j}$ is the quantity of input produced by firm $m$ in sector $i$ that is purchased by firm $l$ in sector $j$, and the weights $\zeta_{i j}$ satisfy $\zeta_{i j} \in[0,1]$ and $\sum_{i=n, d} \zeta_{i j}=1$. The aggregator in (10) is the special case of the CES aggregator where the elasticity of substitution tends to 1 and it has the property that the weight $\zeta_{i j}$ is equal to the share of sector $i$ in the material input expenditures by sector $j$. This property is very useful in the quantitative analysis of the model because the shares can be computed using data from the Use Table of the U.S. Input-Output (I-O) accounts.

Unit-cost minimization determines the demand functions for capital, labor, and materials inputs by the generic firm. Formally,

$$
\underset{\left\{k_{t}^{l j}, n_{t}^{l j}, h_{t}^{l j}\right\}}{\operatorname{Min}} R_{t} k_{t}^{l j}+W_{t}^{j} n_{t}^{l j}+Q_{t}^{j} h_{t}^{l j},
$$

subject to $F\left(k_{t}^{l j}, n_{t}^{l j}, h_{t}^{l j}\right) \geq 1$, where

$$
Q_{t}^{j}=\prod_{i=n, d}\left(P_{t}^{i}\right)^{\zeta_{i j}}
$$

is the price of the composite good $h_{t}^{l j}$. First-order conditions are

$$
\begin{aligned}
R_{t} & =\Psi_{t}^{j} F_{1}\left(K_{t}^{j}, N_{t}^{j}, H_{t}^{j}\right), \\
W_{t}^{j} & =\Psi_{t}^{j} F_{2}\left(K_{t}^{j}, N_{t}^{j}, H_{t}^{j}\right), \\
Q_{t}^{j} & =\Psi_{t}^{j} F_{3}\left(K_{t}^{j}, N_{t}^{j}, H_{t}^{j}\right),
\end{aligned}
$$

where $\Psi_{t}^{j}$ is the Lagrange multiplier associated with the constraint and is equal to the nominal marginal cost in sector $j$, and $F_{x}$ denotes the partial derivative of the function $F(\cdot)$ with respect to its $x^{\text {th }}$ argument. Note that because labor and capital are perfectly mobile within the same sector, and because the production function has constant returns to scale, firms in the same sector will have the same nominal marginal cost and identical capital/labor and capital/materials ratios. Thus, $k_{t}^{l j} / n_{t}^{l j}=K_{t}^{j} / N_{t}^{j}$ and $k_{t}^{l j} / h_{t}^{l j}=K_{t}^{j} / H_{t}^{j}$ where $K_{t}^{j}=\int_{0}^{1} k_{t}^{l j} d l$ and $H_{t}^{j}=\int_{0}^{1} h_{t}^{l j} d l$; and $F_{x}\left(k_{t}^{l j}, n_{t}^{l j}, h_{t}^{l j}\right)=F_{x}\left(K_{t}^{j}, N_{t}^{j}, H_{t}^{j}\right)$. It is possible to show (see Bouakez et al., 2005) that the demand for good $l$ in sector $j$ on the part of firm $m$ in sector $i$ is

$$
h_{l j, t}^{m i}=\zeta_{j i}\left(P_{t}^{l j} / P_{t}^{j}\right)^{-\epsilon}\left(P_{t}^{j} / Q_{t}^{i}\right)^{-1} h_{t}^{m i},
$$

and that, for this demand function, $\sum_{i=n, d} \int_{0}^{1} P_{t}^{m i} h_{m i, t}^{l j} d m=\sum_{i=n, d} P_{t}^{i} h_{i, t}^{l j}=Q_{t}^{j} h_{t}^{l j}$.

Prices are assumed to be sticky as in Calvo (1983) and Yun (1996). In each period, some firms are randomly selected to set new prices. The selection probability in any given period is constant 
and is equal to $1-\theta^{j}$. Let $\tilde{P}_{t}^{j}$ denote the optimal price set by a typical firm in sector $j$ at time $t$. (Note that all firms that are allowed to re-optimize in a given period will end up choosing the same price, since they face the same technological and budget constraints.) A firm that has the opportunity to re-optimize at time $t$ faces total demand

$$
\tilde{Y}_{s}^{j} \equiv \tilde{C}_{s}^{j}+\sum_{i=n, d}\left(\int_{0}^{1} \tilde{h}_{j, s}^{m i} d m\right)
$$

in period $s$, where

$$
\begin{aligned}
\tilde{C}_{s}^{j} & =\left(\tilde{P}_{t}^{j} / P_{s}^{j}\right)^{-\epsilon} C_{t}^{j} \\
\tilde{h}_{j, s}^{m i} & =\zeta_{j i}\left(\tilde{P}_{t}^{j} / P_{s}^{j}\right)^{-\epsilon}\left(P_{s}^{j} / Q_{s}^{i}\right)^{-1} h_{t}^{m i} .
\end{aligned}
$$

The firm chooses $\tilde{P}_{t}^{j}$ to maximize the discounted sum of its real profits, which will be transferred to shareholders in the form of dividends,

$$
E_{t} \sum_{s=t}^{\infty}\left(\beta \theta^{j}\right)^{s-t} \varphi_{s, t}^{j}\left(\pi_{s}^{l j} / P_{s}\right)
$$

where $P_{t}$ is the aggregate price index, $\varphi_{s, t}^{j}$ is the ratio of marginal utilities of the good produced in sector $j$ between periods $t$ and $s$, and

$$
\pi_{s}^{l j}=\left(\tilde{P}_{t}^{j}-\Psi_{s}^{j}\right)\left(\tilde{C}_{s}^{j}+\sum_{i=n, d}\left(\int_{0}^{1} \tilde{h}_{j, s}^{m i} d m\right)\right) .
$$

The first-order condition for this problem yields

$$
\tilde{P}_{t}^{j}=\vartheta\left(\frac{E_{t s=t}^{\infty}\left(\beta \theta^{j}\right)^{s-t} \varphi_{s}^{j}\left(P_{s}^{j}\right)^{\epsilon} \Psi_{s}^{j} \tilde{Y}_{s}^{j}}{E_{t} \sum_{s=t}^{\infty}\left(\beta \theta^{j}\right)^{s-t} \varphi_{s}^{j}\left(P_{s}^{j}\right)^{\epsilon-1} \tilde{Y}_{s}^{j}}\right),
$$

where $\vartheta=\epsilon /(\epsilon-1)$ is the markup that would prevail if prices were fully flexible.

\subsection{The Government}

The government finances the transfers to households by printing additional money, and so its budget constraint is

$$
T_{t}=M_{t}-M_{t-1}
$$

As in Barsky et al. (2007), it is further assumed that money supply follows a random walk

$$
M_{t}=M_{t-1}+\xi_{t}
$$

where $\xi_{t}$ is an independently and identically distributed (i.i.d.) disturbance with zero mean. 


\subsection{Aggregation Within Sectors}

Since firms within the same sector are not identical in terms of their position in the price distribution, aggregation within sectors is not trivial. To solve the model, we need to relate the supply and demand for each composite good $j$. Let $Y_{t}^{j}$ denote total output produced by sector $j$ :

$$
Y_{t}^{j}=\int_{0}^{1} F\left(k_{t}^{l j}, n_{t}^{l j}, h_{t}^{l j}\right) d l=F\left(K_{t}^{j}, N_{t}^{j}, H_{t}^{j}\right),
$$

where the second equality holds because the production function $F(\cdot)$ is constant returns to scale. In equilibrium, the total supply of all goods produced in sector $j$ must equal the total demand for these goods, meaning that

$$
\begin{aligned}
Y_{t}^{j} & =\int_{0}^{1} C_{s}^{l j} d l+\sum_{i=n, d}\left(\int_{0}^{1} \int_{0}^{1} h_{l j, s}^{m i} d m d l\right) \\
& =\left(C_{t}^{j}+\sum_{i=n, d} \zeta_{j i}\left(P_{t}^{j} / Q_{t}^{i}\right)^{-1} H_{t}^{i}\right)\left(\frac{\mathcal{P}_{t}^{j}}{P_{t}^{j}}\right)^{-\epsilon},
\end{aligned}
$$

where $P_{t}^{j} \equiv\left(\int_{0}^{1}\left(P_{t}^{l j}\right)^{-\epsilon} d l\right)^{-1 / \epsilon}$ and the term between brackets denotes the total demand for the composite good $j$.

\subsection{Aggregation Across Sectors}

In equilibrium, private bond holdings equal to zero because households are identical. Thus, the aggregate counterpart of the representative household's budget constraint is

$$
\sum_{j=n, d} P_{t}^{j} C_{t}^{j}=R_{t} K+\sum_{j=n, d} W_{t}^{j} N_{t}^{j}+\sum_{j=n, d} \Pi_{t}^{j}
$$

where $\Pi_{t}^{j}=\int_{0}^{1} \pi_{t}^{l j} d l$. Let $G_{t}^{j}$ denote the value of gross output produced by sector $j$. Then, aggregate nominal dividends are equal to

$$
\sum_{j=n, d} \Pi_{t}^{j}=\sum_{j=n, d} G_{t}^{j}-R_{t} K-\sum_{j=n, d} W_{t}^{j} N_{t}^{j}-\sum_{j=n, d} Q_{t}^{j} H_{t}^{j} .
$$

Let $Y_{t}^{j}$ denote the nominal value added in sector $j$ which is defined as the value of gross output produced by that sector minus the cost of material inputs. That is,

$$
\mathcal{Y}_{t}^{j}=G_{t}^{j}-Q_{t}^{j} H_{t}^{j} .
$$

Substituting (18) and (19) into (17), and rearranging yields

$$
\sum_{j=n, d} \mathcal{Y}_{t}^{j}=\sum_{j=n, d} P_{t}^{j} C_{t}^{j} .
$$

Thus, total nominal output equals the value of newly purchased nondurable and durable goods. 


\section{Calibration}

The quantitative implications of the model are studied using a calibration that closely follows the baseline case in Barsky et al. (2007). Hence, a period in the model corresponds to one hundredth of a year; the functional forms of the subutility functions are

$$
\begin{aligned}
U\left(C_{t}^{n}, D_{t}\right) & =\psi \ln C_{t}^{n}+(1-\psi) \ln D_{t}, \\
V\left(N_{t}\right) & =\phi\left(\frac{\eta}{\eta+1}\right) N_{t}^{\frac{\eta+1}{\eta}},
\end{aligned}
$$

where $\psi \in(0,1), \phi, \eta>0$, and $\eta \neq-1$; and the production function of each firm in each sector is Cobb-Douglas

$$
F\left(k_{t}^{l j}, n_{t}^{l j}, h_{t}^{l j}\right)=\left(k_{t}^{l j}\right)^{\alpha^{j}}\left(n_{t}^{l j}\right)^{\nu^{j}}\left(h_{t}^{l j}\right)^{\mu^{j}},
$$

where $\alpha^{j}, \nu^{j}, \mu^{j} \in(0,1)$ and $\alpha^{j}+\nu^{j}+\mu^{j}=1$. The parameter values are listed in Table 2. The utility weight, $\psi$, is set so that durable goods represent 25 percent of consumption expenditures in the steady state. The subjective discount factor, $\beta$, is set so as to yield an annual risk free interest rate of 4 percent. The elasticity of substitution between goods within each sector is set to 11 , implying an average markup of 10 percent. The probability of not changing prices in the durablegood sector implies a half life of price spells of 2 quarters, whereas prices in the nondurable-good sector are assumed to be completely flexible.

Our extension of the baseline model in Barsky et al. (2007) introduces additional parameters which are calibrated as follows. The parameter $\varsigma$, which determines the elasticity of substitution between hours worked in different sectors, is set to 1 based on the empirical work by Horvath (2000). Horvath estimates $\varsigma$ from an Ordinary Least Square regression of the change in the relative labor supply on the change in the relative labor share using sectoral U.S. data and finds $\varsigma=0.9996$ with a standard error of 0.0027 .

We estimate the production function parameters using yearly data on nominal expenditures on capital, labor and material inputs by sector collected by Dale Jorgenson for the period 1958 to 1996. Jorgenson's data cover more than 30 sectors but they can be easily aggregated into two sectors (durables and nondurables) using the BLS definition of durability. The estimation strategy is the same as in Bouakez et al. (2005). Using the assumption of Cobb-Douglas production functions 
and the first-order conditions of the firm's cost-minimization problem write ${ }^{7}$

$$
\begin{aligned}
\alpha^{j} \Psi_{t}^{j} & =R_{t} K_{t}^{j} / Y_{t}^{j}, \\
\nu^{j} \Psi_{t}^{j} & =W_{t}^{j} N_{t}^{j} / Y_{t}^{j}, \\
\mu^{j} \Psi_{t}^{j} & =\sum_{i=n, d} P_{t}^{i} H_{i, t}^{j} / Y_{t}^{j} .
\end{aligned}
$$

The right-hand sides of these equations are, respectively, the output shares of expenditures on capital, labor, and material inputs. Jorgenson's data are empirical equivalents of $R_{t} K_{t}^{j}, W_{t}^{j} N_{t}^{j}$, and $\sum_{i=n, d} P_{t}^{i} H_{i, t}^{j}$. The marginal cost, $\Psi_{t}^{j}$, is not directly observable, but estimates of $\alpha^{j}, \nu^{j}$, and $\mu^{j}$ may be constructed using the ratios $(21) /(23)$ and $(22) /(23)$, and the condition $\alpha^{j}+\nu^{j}+\mu^{j}=1$ to obtain a system of three equations with three unknowns. The unique solution of this system delivers an observation of the production function parameters for that year. Estimates of $\alpha^{j}, \nu^{j}$, and $\mu^{j}$ are the sample averages of these yearly observations and are reported in Table $2 .{ }^{8}$

The input weights $\zeta_{i j}$ are computed using data from the U.S. Input-Output (I-O) accounts, prepared by the Bureau of Economic Analysis (BEA). More precisely, the shares are constructed using the 1992 Use Table, which contains the value in producer prices of each input used by each U.S. industry. As before, industries are aggregated into durables and nondurables based on the BLS definition of durability. The estimated input-output matrix is that reported in Table 1 and indicates that the nondurables sector provides most of the materials inputs used in durable and nondurable production. Specifically, nondurable goods represent roughly 70 percent of the materials inputs used in the production of durable goods. ${ }^{9}$

\section{The Implications of Durability}

The implications of durability for the transmission of monetary policy shocks is studied here (as in Barsky et al.) by means of impulse response analysis. In particular, we consider the response of the economy to a 1 percent permanent increase in the money supply under different assumptions regarding inter-sectoral linkages and labor mobility. First, we replicate the results in Barsky et al. using a restricted version of our model. The intention is to show that their model may be obtained as a special case of ours under certain parametric restrictions so that the difference in results is only due to the two additional features in the general model rather than to a different

\footnotetext{
${ }^{7}$ The firm subscript is dropped because, in equilibrium, firms in the same sector use identical labor-, capital- and materials-output ratios.

${ }^{8}$ For additional details and caveats, see Bouakez et al. (2005).

${ }^{9}$ Although I-O tables do evolve over time, for example as a result of technological innovation, sensitivity analysis reported below indicates that our results are robust to perturbations around the calibrated values.
} 
calibration. Then, we report results from the general model and show that incorporating durable goods into a more realistic sticky-price model does not lead to aggregate neutrality and negative sectoral comovement, even if durable prices are flexible. In order to develop the intuition regarding the relative role of input-output interactions and imperfect labor mobility, we also report results from two restricted versions of the model where one of the two features is respectively shut down.

\subsection{Model by Barsky et al. (2007)}

In the special case of no materials inputs $\left(\alpha^{j}=0.35, \nu^{j}=0.65\right.$, and $\mu^{j}=0$ for $\left.j=n, d\right)$ and perfect labor mobility $(\varsigma \rightarrow \infty)$, our model boils down to that in Barsky et al. ${ }^{10}$ Figure 2 shows that following the monetary expansion, there is a large decline in nondurable consumption (and production, since there are no materials) that almost exactly offsets the increase in nondurable consumption, leaving aggregate output virtually unchanged (output increases by less than 0.04 percent on impact). The price of durables initially overshoots before converging to its new steadystate level from above, while the price of nondurables adjusts gradually, reaching its new steadystate level from below. As for the aggregate price level, it varies in exact proportion with changes in the money stock. This figure reproduces the results in Barsky et al. (2007, Figure 1). When durable goods have flexible prices, money is essentially neutral at the aggregate level and there is a negative comovement of sectoral consumption and production following a monetary expansion.

Barsky et al. provide an elegant analytic explanation for both results and show that they stem primarily from the near constancy of the shadow value of durable goods, $\gamma_{t}$. To see this, note that when there is perfect labor mobility, the nominal wage is equated across sectors and Equation (8) becomes

$$
V^{\prime}\left(N_{t}\right)=\lambda_{t} W_{t}=\frac{\gamma_{t}}{P_{t}^{d}} W_{t}=\frac{\gamma_{t}}{\vartheta \Psi_{t}} W_{t}
$$

where the second equality follows from the first-order condition (6) and the last equality is implied by the fact that the (flexible) price of durables is equal to a constant markup over nominal marginal cost. Since factors of production are free to flow from one sector to the other, and since the production functions in both sectors have constant returns to scale, all firms have the same marginal cost and choose the same capital/labor ratio. Thus,

$$
W_{t}=\Psi_{t} F_{2}\left(K_{t}^{d}, N_{t}^{d}\right)=\Psi_{t} F_{2}\left(K, N_{t}\right)=\Psi_{t} f\left(N_{t}\right)
$$

where $f\left(N_{t}\right)=F_{2}\left(K, N_{t}\right)$. Combining (24) and (25) yields

$$
V^{\prime}\left(N_{t}\right)=\frac{\gamma_{t}}{\vartheta} f\left(N_{t}\right)
$$

\footnotetext{
${ }^{10}$ In practice, we set $\varsigma$ to $10^{5}$, but using similarly large values leads to the same results.
} 
If $\gamma_{t}$ is constant, this equation implies that aggregate employment is equal to its steady-state level in every period. Therefore, the near constancy of the shadow value of durable goods means that aggregate employment and output remain almost unchanged following the monetary policy shock.

Similarly, the negative sectoral comovement can be easily understood from the first-order conditions (5) and (7), which may be combined to yield

$$
\frac{\psi}{C_{t}^{n}}=\gamma_{t} \frac{P_{t}^{n}}{P_{t}^{d}}
$$

Since $\gamma_{t}$ is approximately constant and the relative price of nondurable goods decreases following a monetary expansion (due to the stickiness of the nominal price of these goods), nondurable consumption must increase. With aggregate output being roughly constant and nondurable consumption increasing, durable consumption must necessarily fall in response to a monetary expansion.

\subsection{Model with Imperfect Labor Mobility and Inter-Sectoral Linkages}

Now, consider the model augmented with materials inputs and imperfect labor mobility. The impulse responses generated by this model are depicted in Figure 3. In this case, following the monetary expansion, production and consumption increase in both sectors, which in turn results in a large positive effect on aggregate output. The aggregate price level moves less than one for one with changes in the money supply, and converges gradually from below to its new steady-state

level. Aggregate neutrality and the negative sectoral comovement are no longer a feature of the sticky-price model with durable goods once one introduces input-output interactions and limited labor mobility. In addition, the positive correlation in sectoral output responses to monetary policy shocks is consistent with evidence from Vector Autoregressions (VAR) reported in Barth and Ramey (2001), Dedola and Lippi (2003), Peersman and Smets (2005) and Erceg and Levin (2006).

To understand the intuition for these results, it is useful to inspect the analogous of equation (26) in the extended model:

$$
V^{\prime}\left(N_{t}\right) \frac{\partial N_{t}}{\partial N_{t}^{d}}=\frac{\gamma_{t}}{\vartheta} F_{2}\left(K_{t}^{d}, N_{t}^{d}, H_{t}^{d}\right)
$$

Unlike Equation (26), this equation does not imply that the monetary policy shock is neutral with respect to aggregate employment. First, because labor mobility is now limited, the increase in production costs in the nondurables sector is only partly passed through to the durables sector. In particular, wages in the durables sector need not increase by as much as when labor is perfectly mobile. This mitigates the increase in the marginal cost and the price of durables, and, therefore, 
the effect on durable consumption. ${ }^{11}$ Second, the estimated input-output table indicates that the nondurables sector provides a large share of materials inputs entering the production of durable goods. Since the price of nondurables is sticky, those goods become relatively cheap following a positive monetary policy shock. Thus, firms in the durables sector need not cut their production by as much as in the Barsky et al. model. In turn, the resulting moderate increase in the marginal cost implies a modest increase in the price of durables, thus preventing a large decline in durable consumption.

To understand why durable production and consumption actually increase, it is easier to assume that $K_{t}^{d}$ is fixed. By assumption, if aggregate employment increases, then $V^{\prime}\left(N_{t}\right)$ also increases. Owing to the near constancy of the shadow value of durable goods and to the fact that $\partial N_{t} / \partial N_{t}^{d}$ is positive, Equation (27) implies that the marginal product of labor must also increase. Without materials inputs, this requires that $N_{t}^{d}$ decreases, which also means that $N_{t}^{n}$ must increase (otherwise $N_{t}$ would fall), leading to negative comovement of employment and output across sectors. In the presence of materials inputs, however, the rise in the marginal product of labor can be achieved through an increase in $H_{t}^{d}$, so that $N_{t}^{d}$ need not fall. If both $H_{t}^{d}$ and $N_{t}^{d}$ increase or if the rise in $H_{t}^{d}$ is large enough to offset the fall in $N_{t}^{d}$, then durable production increases. The positive income effect resulting from higher labor income triggers an increase in durable consumption. In this case, there is positive comovement of production and consumption across sectors. As stated above, this intuition is based on the premise that $K_{t}^{d}$ is fixed, but in fact, it will hold even when capital is mobile across sectors as long as $K_{t}^{d}$ does not fall too much in response to the monetary expansion, which is precisely what Figure 3 shows.

In order to understand the separate role of imperfect labor mobility and input-output interactions in delivering aggregate non-neutrality and positive sectoral comovements following a monetary policy shock, it is instructive to examine two special cases that are nested in our model: one that allows for imperfect labor mobility but abstracts from materials inputs and one that allows for materials inputs but where labor is perfectly mobile across sectors.

\subsubsection{Case 1: Imperfect labor mobility but no materials inputs}

This case is obtained by setting the production function parameters to $\alpha=0.35, \nu=0.65$ and $\mu=0$ in both sectors, while keeping all other parameter values fixed. The effects of a 1 percent permanent shock to the money supply are reported in Figure 4. One can observe an initial 1.5 percent increase in nondurable consumption and a 2 percent decline in durable consumption. These

\footnotetext{
${ }^{11}$ Any friction that impedes labor mobility across sectors would generate this effect. This suggests that our results do not depend on the particular manner in which imperfect labor mobility is modeled.
} 
responses are quantitatively smaller than those reported in Barsky et al. (see Figure 1), and since the relative decline in durable consumption is much smaller in this case, it does not counterbalance the increase in nondurable consumption so that aggregate output increases by 0.6 percent in the period following the shock. Thus, we conclude that the aggregate neutrality property in Barsky et al. is not robust to relaxing the assumption of perfect labor mobility. ${ }^{12}$ On the other hand, it is clear that the negative comovement of consumption and production across sectors is robust to relaxing this assumption. The reason is simply that for aggregate output to rise following the monetary expansion, total hours worked $\left(N_{t}\right)$ must increase since the aggregate capital stock is fixed. This means that the marginal product of labor has to increase in the durables sector, which requires $N_{t}^{d}$ to fall (since $K_{t}^{d}$ also decreases).

\subsubsection{Case 2: Materials inputs but perfect labor mobility}

The second variant that we consider allows for the use of materials inputs in production according to the estimated input-output table, but assumes that labor is perfectly mobile across sectors. Results for this case are shown in Figure 5. Following the monetary expansion, consumption moves in opposite directions across the two sectors, although to a lesser extent than in the Barsky et al. model, rising by 1.1 percent in the nondurables sector and falling only by 5 percent in the durables sector. As a result, aggregate output increases by roughly 0.7 percent. Production, on the other hand, rises by about 1.8 percent in the nondurables sector but remains essentially unchanged in the durables sector. Hence, sectoral interaction through the use of materials inputs restores aggregate nonneutrality of monetary policy shocks but is insufficient to induce positive comovement of sectoral consumption and production. The fact that durables use as inputs a large fraction of nondurable materials, which become relatively cheap following the monetary expansion, attenuates the decline in employment in the durables sector. Perfect labor mobility, however, implies that wages in the durables sector rise by as much as in the nondurables sector, which amplifies the rise in the marginal cost and the price of durable goods relative to the case with restricted labor mobility. This generates a strong relative-price effect that dominates the income effect (resulting from higher labor income) in the durables sector and leads to a decline in durable consumption.

In summary, these results suggest that sectoral interaction and imperfect labor mobility are mutually reinforcing ingredients that generate strong aggregate effects of monetary policy shocks and positive comovement of sectoral consumption and production. Both features dampen the increase in the marginal cost of producing durable goods that results from an expansionary monetary policy. This translates into a more moderate price increase and a milder decline in durable con-

\footnotetext{
${ }^{12}$ This point is already acknowledged by Barsky et al. (p. 991).
} 
sumption that is insufficient to offset the increase in nondurable consumption, thereby implying aggregate nonneutrality. Together, the two features also imply that employment need not fall in the nondurables sector when aggregate employment rises, which leads to positive comovement of employment and output across sectors.

\subsection{Sensitivity Analysis}

In this section, we study the sensitivity of our results to perturbations in the values of key parameters. We consider three alternative scenarios: one with a higher degree of labor mobility, one with an alternative input-output matrix that involves a smaller share of nondurables inputs used to produce durable goods, and one with a minimal degree of stickiness in the price of durable goods. The impulse responses to a 1 percent permanent increase in money supply obtained under each of these scenarios are shown, respectively, in Panels A, B, and C of Figure 6.

Consider first the case with increased labor mobility. The extent to which labor flows freely across sectors is governed by the elasticity of substitution between hours worked in the different sectors, which in turn depends on the parameter $\varsigma$. In our baseline calibration, we set $\varsigma=1$ but now allow for more labor mobility by setting $\varsigma=2$. Larger values of $\varsigma$ imply smaller differences in wages across sectors. This also means that there is a larger increase in the marginal cost of producing durable goods following a monetary expansion, which exerts a downward pressure on employment in the durables sector. Nonetheless, this pressure is not strong enough to reverse the positive comovement of production and consumption across sectors, as shown in Panel A of Figure 6.

Second, we examine the extent to which our results depend on the particular structure of the input-output matrix computed from U.S. data. The discussion in Section 3 suggests that the feature of this matrix that is relevant to our results is the large fraction of nondurables inputs entering the production of durable goods. In our baseline calibration, this fraction (measured by the parameter $\left.\zeta_{n d}\right)$ was equal to 0.668 , but in this experiment, we set $\zeta_{n d}=0.5$. The results, shown in Panel B of Figure 6, indicate that even when only 50 percent of inputs in durables are provided by the nondurables sector, there is still positive sectoral comovement of consumption and production conditional on a monetary policy shock. As should be expected, however, the extent of this positive comovement decreases as $\zeta_{n d}$ becomes smaller.

Finally, consider the case where the price of durable goods is not fully flexible. More specifically, we set the Calvo parameter $\theta^{d}$ such that the half life of price spells in the durables sector is equal to two weeks. This negligible amount of price rigidity is still consistent with the conventional view that durables have much less rigid prices than nondurables. Panel $\mathrm{C}$ of Figure 6 shows that allowing for 
a minimal degree of price stickiness in the durables sector has a strong impact on the response of this sector to a monetary policy shock. Following a monetary expansion, durable consumption and production increase substantially more than in Figure 2, where durables prices are fully flexible. These responses are also larger in magnitude than their counterparts in the nondurables sector. This result is in line with VAR evidence that durables tend to be more highly sensitive to monetary policy shocks than nondurables (see, for example, Barth and Ramey, 2001, and Erceg and Levin, 2006).

\section{Conclusions}

This paper has shown that the negative sectoral comovement and potential money neutrality in sticky-price models with durables reported in Barsky et al. are not generally robust to input-output interactions and imperfect mobility of productive inputs. These two features are apparent in the data and, as durability, should be ingredients of a well-specified sticky-price model. Bouakez et al. (2005) show that inter-sectoral linkages are important to understand the transmission of monetary policy and its aggregate effects. The paper by Barsky et al. provides yet another argument for macroeconomists to care about sectoral interactions. 


\section{Table 1. U.S. Input-Output Matrix 1992}

\begin{tabular}{lcc}
\hline \hline \multirow{2}{*}{ Producer } & \multicolumn{2}{c}{ Consumer } \\
\cline { 2 - 3 } & Nondurables & Durables \\
\hline Nondurables & 0.899 & 0.688 \\
Durables & 0.101 & 0.312 \\
& & \\
\hline
\end{tabular}

Notes: This Table reports the share of total material-input expenditures by the consuming sector that goes into goods from the producing sector. Thus, 68.8 percent of the material-input expenditure by the durables sector goes into goods produced by the nondurables sector. The shares were computed by the authors using the table "The Use of Commodities by Industries" for 1992 produced by the BLS. 
Table 2. Parameter Values

\begin{tabular}{ll}
\hline \hline Preferences & $\psi=0.682, \beta=0.9998, \delta=0.0005, \eta=1, \varsigma=1$ \\
Market structure & $\epsilon=11$ \\
Calvo probabilities & $\theta^{n}=0.987, \theta^{d}=0$ \\
Production functions & $\alpha^{n}=0.193, \nu^{n}=0.340, \mu^{n}=0.467$ \\
& $\alpha^{d}=0.087, \nu^{d}=0.341, \mu^{d}=0.572$ \\
\hline
\end{tabular}

Notes: A period in the model corresponds to one hundredth of a year. 


\section{References}

[1] Barth, M. J., and Ramey, V. A., (2001), "The Cost Channel of Monetary Transmission," NBER Macroeconomics Annual 16, pp. 199-239.

[2] Barsky, R. B., House, C. and Kimball, M. S., (2007), American Economic Review 97, pp. 984-998.

[3] Bouakez, H., Cardia, E., and Ruge-Murcia, F. J., (2005), "The Transmission of Monetary Policy in a Multi-Sector Economy," International Economic Review, forthcoming.

[4] Carlstrom, C. and Fuerst, T., (2006), "Co-Movement in Sticky Price Models with Durable Goods," Federal Reserve Bank of Cleveland, Working Paper 0614.

[5] Calvo, G. A., (1983), "Staggered Prices in a Utility-Maximizing Framework," Journal of Monetary Economics 12, pp. 383-398.

[6] Davis, S. J. and Haltiwanger, J., (1991), "Wage Dispersion Between and Within U.S. Manufacturing Plants, 1963-1986," NBER Working Paper No. 3722.

[7] Davis, S. J. and Haltiwanger, J., (2001), "Sectoral Job Creation and Destruction Responses to Oil Price Changes," Journal of Monetary Economics 48, pp. 465-512.

[8] Dedola, L. and Lippi, F. (2005), "The Monetary Transmission Mechanism: Evidence from the Industries of Five OECD Countries," European Economic Review 49, 1543-1569.

[9] Erceg, C. J. and Levin, A., (2006), "Optimal Monetary Policy with Durable Consumption Goods," Journal of Monetary Economics 53, pp. 1341-1359.

[10] Horvath, M., (2000), "Sectoral Shocks and Aggregate Fluctuations," Journal of Monetary Economics 45, pp. 69-106.

[11] Jorgenson, D. W., and Stiroh, K. J., (2000), "Rising the Speed Limit: U.S. Economic Growth in the Information Age," Brookings Papers on Economic Activity, pp. 125-235.

[12] Peersman, G. and Smets, F., (2005), "The Industry Effects of Monetary Policy in the Euro Area," Economic Journal 115, pp. 319-342.

[13] Ramey, V. A. and Shapiro, M., (2001), "Displaced Capital: A Study of Aerospace Plant Closings," Journal of Political Economy 109, pp. 958-992. 
[14] Yun, T., (1996), "Nominal Price Rigidity, Money Supply Endogeneity, and Business Cycles," Journal of Monetary Economics 37, 345-370. 


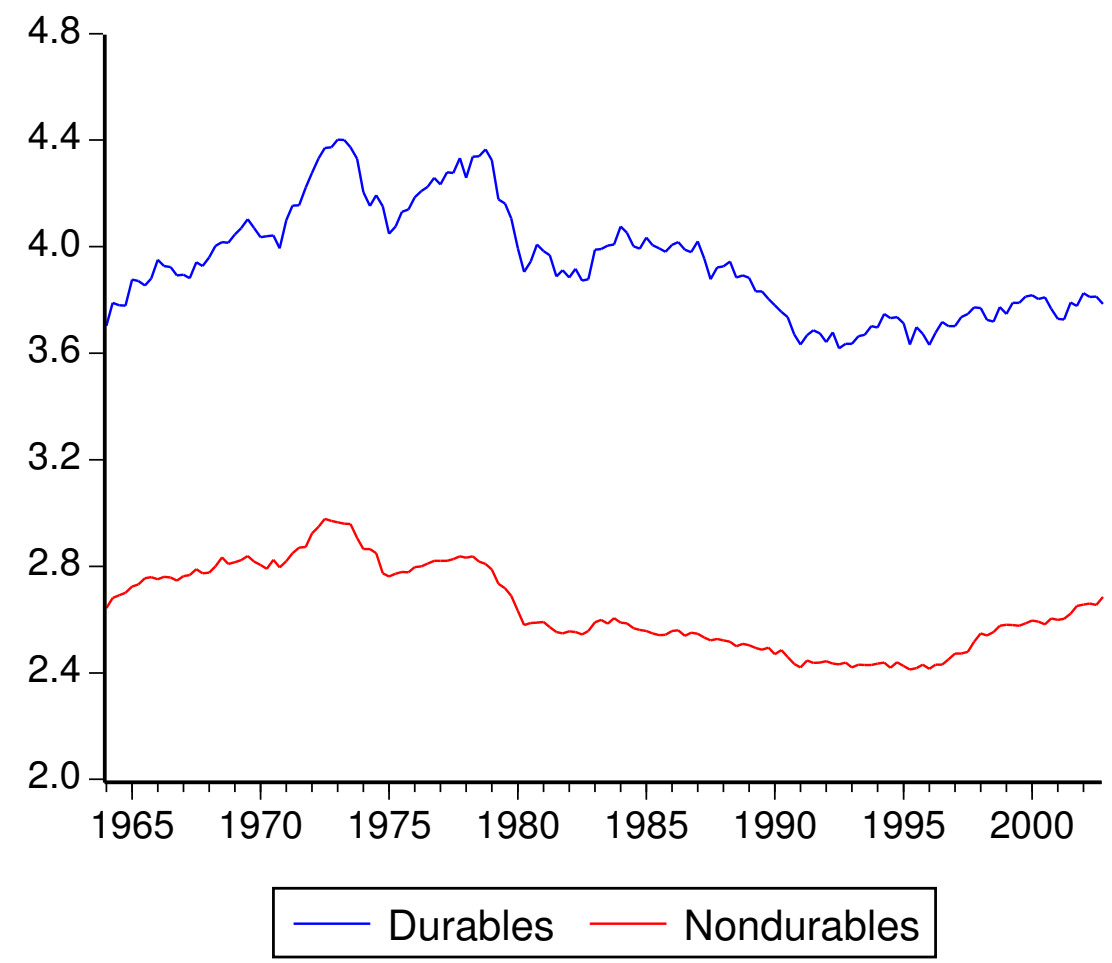

Figure 1: Real average weekly earnings by sector. 
Aggregate real output

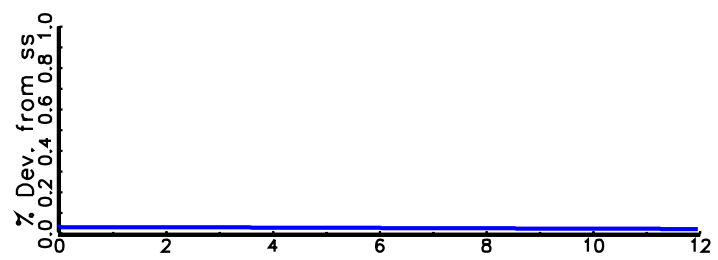

Consumption and production: Nondurables

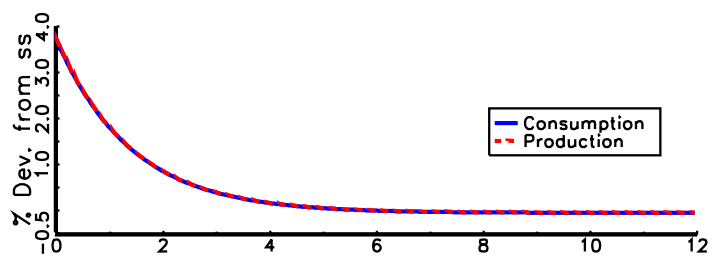

Consumption and production: Durables

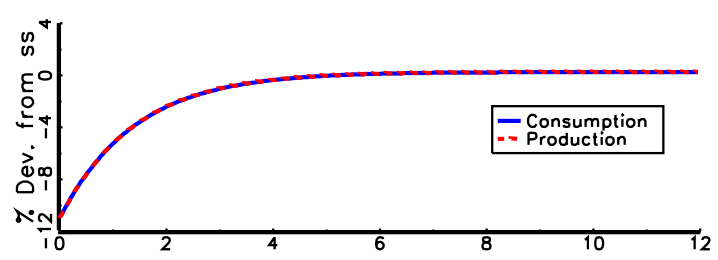

Production inputs: Nondurables

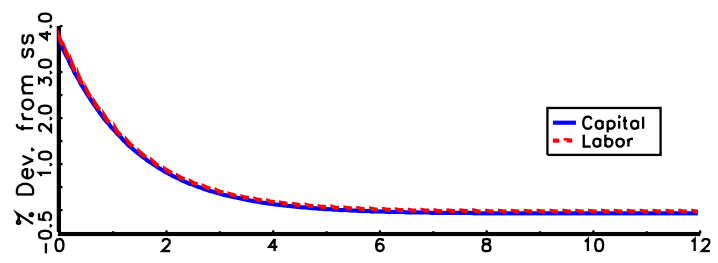

Production inputs: Durables

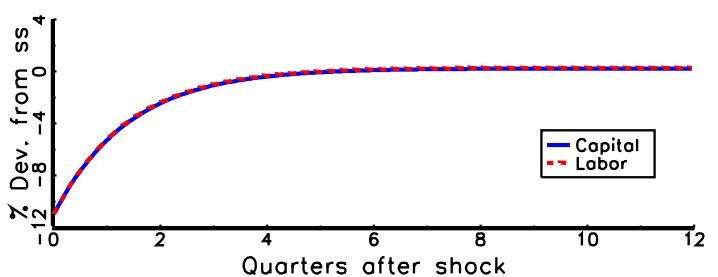

Aggregate price level

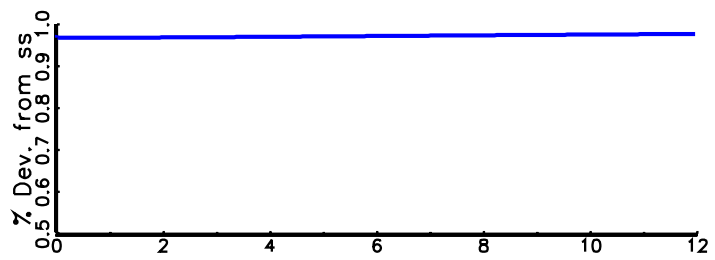

Price: Nondurables

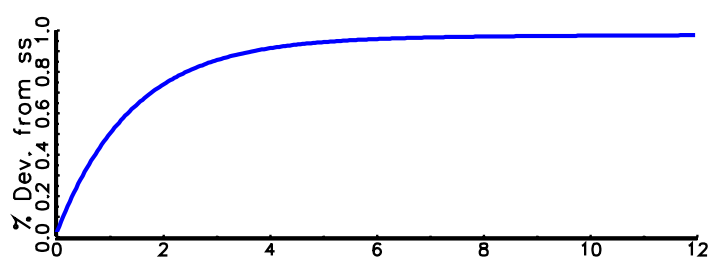

Price: Durables

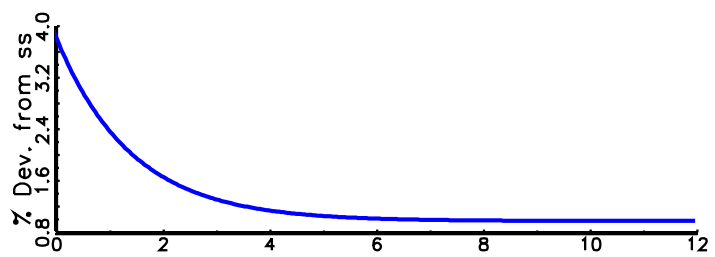

Nominal marginal cost: Nondurables

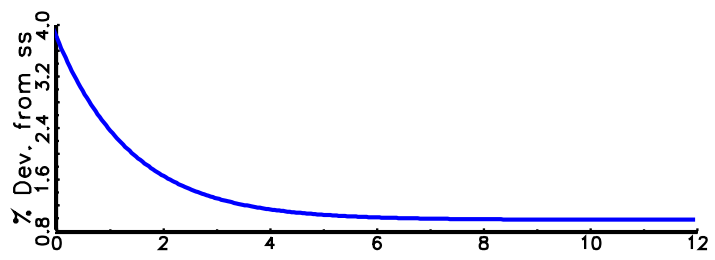

Nominal marginal cost: Durables

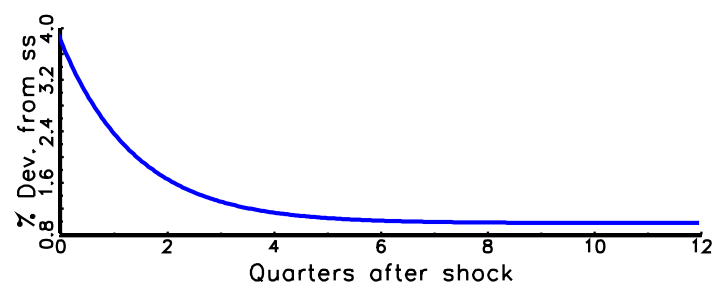

Figure 2: Impulse responses to a 1 percent permanent increase in money supply: Barsky et al.'s model. 
Aggregate real output

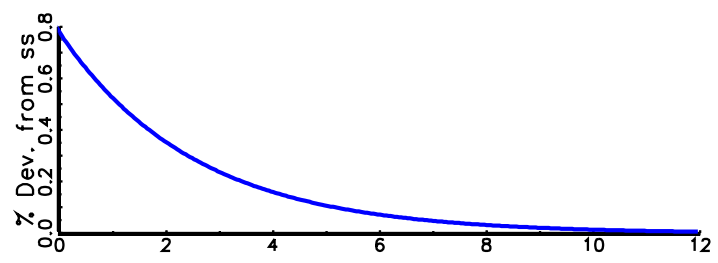

Consumption and production: Nondurables

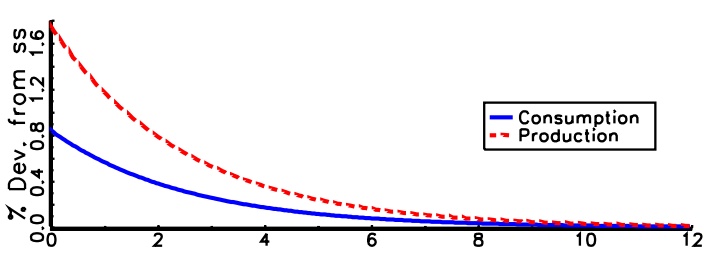

Consumption and production: Durables

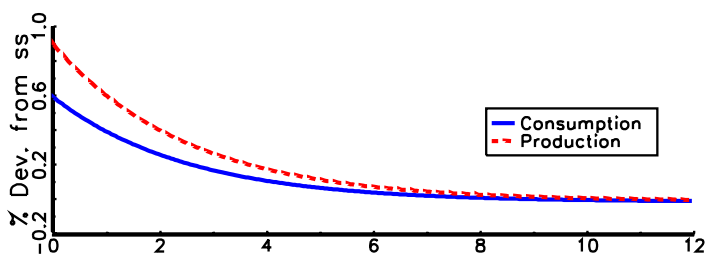

Production inputs: Nondurables

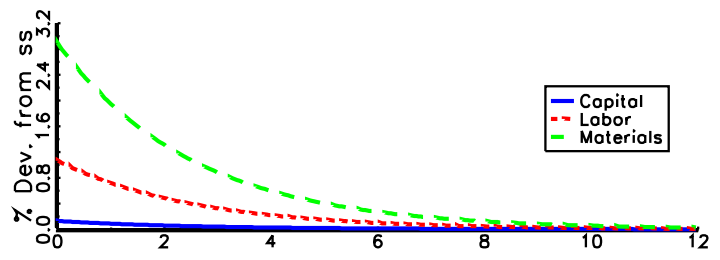

Production inputs: Durables

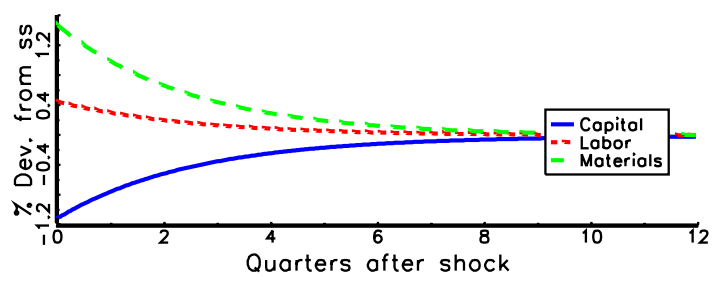

Aggregate price level

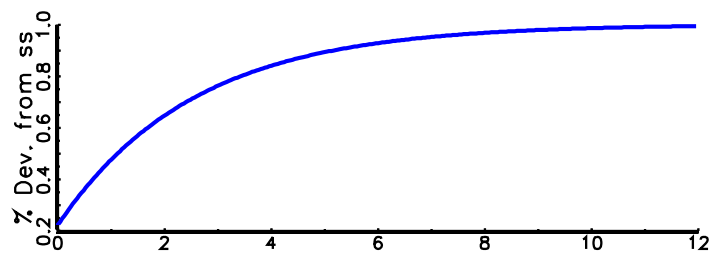

Price: Nondurables

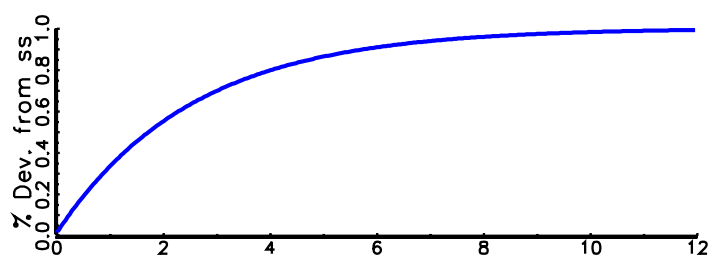

Price: Durables

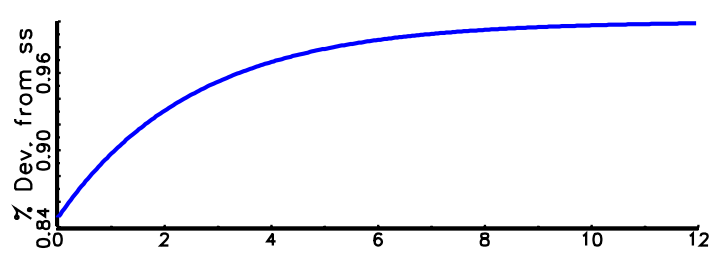

Nominal marginal cost: Nondurables

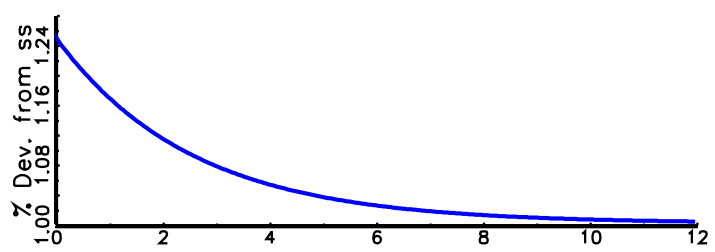

Nominal marginal cost: Durables

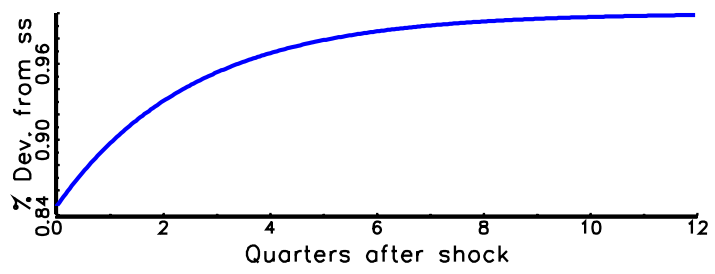

Figure 3: Impulse responses to a 1 percent permanent increase in money supply: Model with imperfect labor mobility and materials inputs. 
Aggregate real output

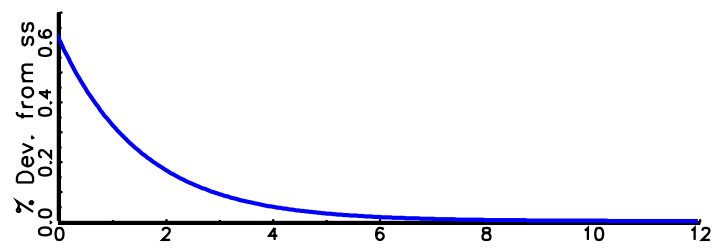

Consumption and production: Nondurables

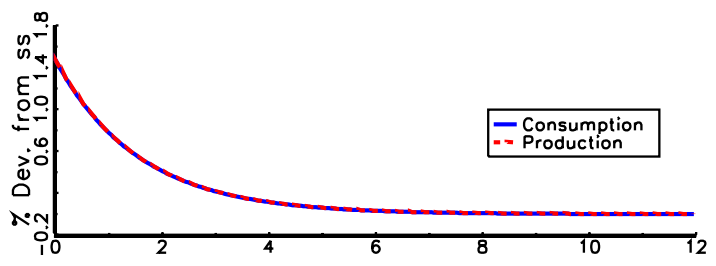

Consumption and production: Durables

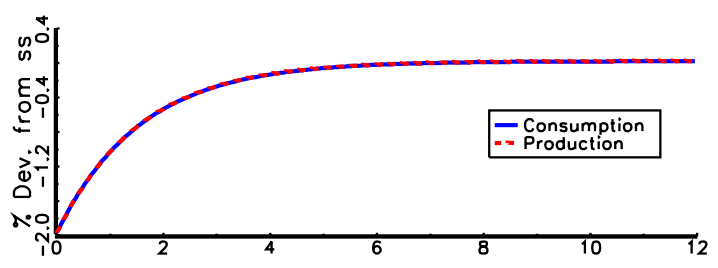

Production inputs: Nondurables

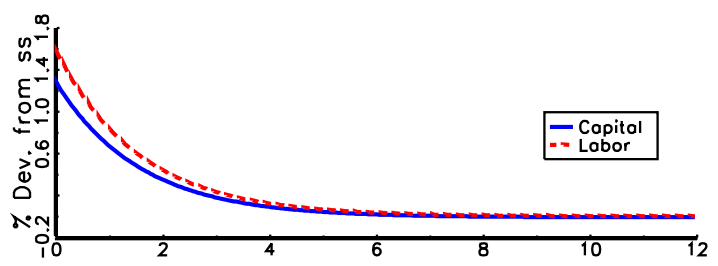

Production inputs: Durables

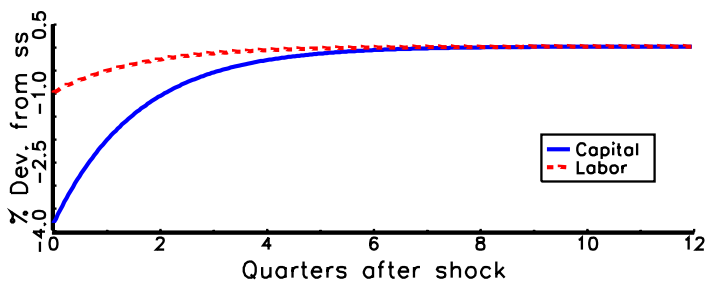

Aggregate price level

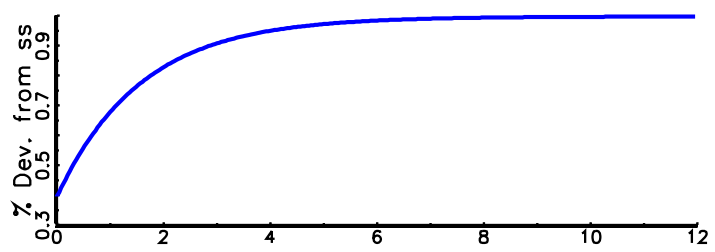

Price: Nondurables

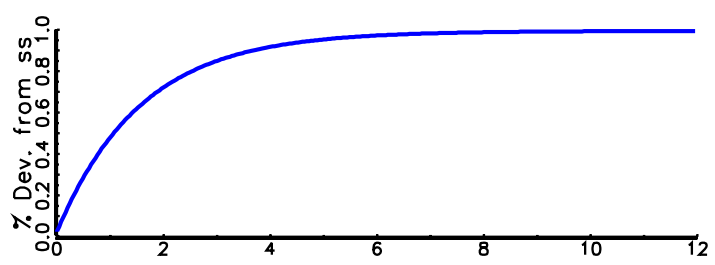

Price: Durables

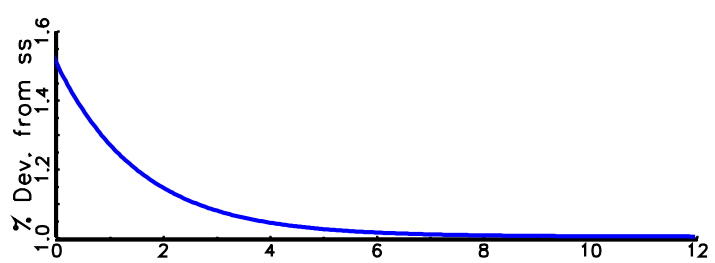

Nominal marginal cost: Nondurables

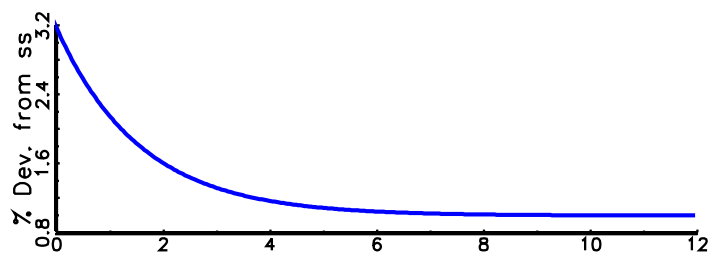

Nominal marginal cost: Durables

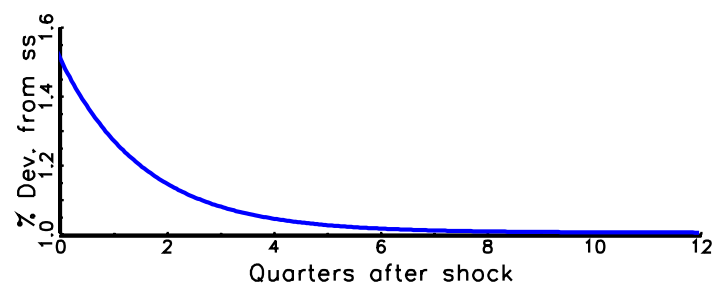

Figure 4: Impulse responses to a 1 percent permanent increase in money supply: Model with imperfect labor mobility but without materials inputs. 
Aggregate real output

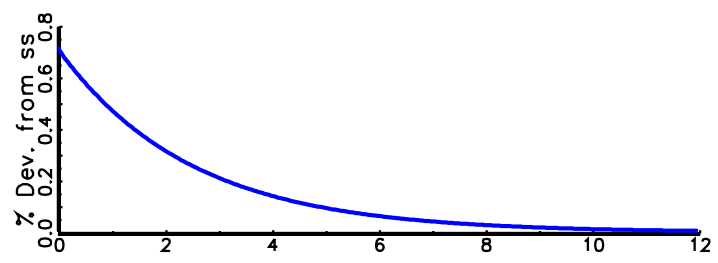

Consumption and production: Nondurables

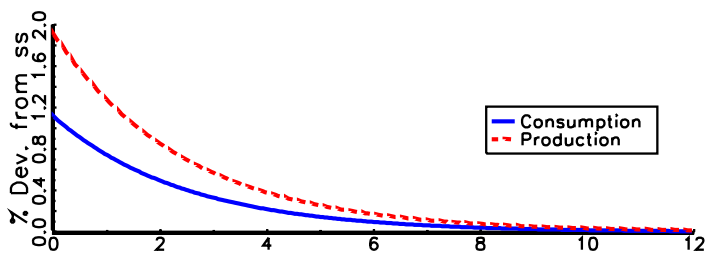

Consumption and production: Durables

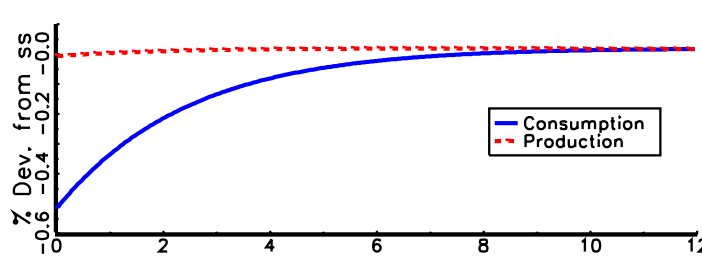

Production inputs: Nondurables

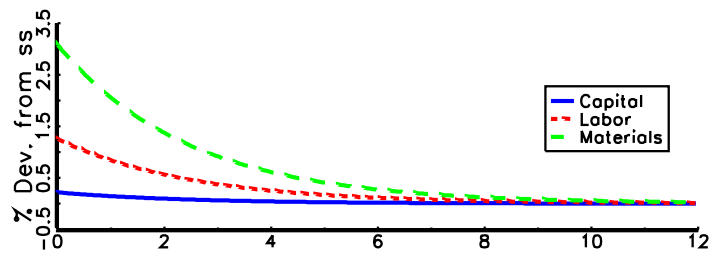

Production inputs: Durables

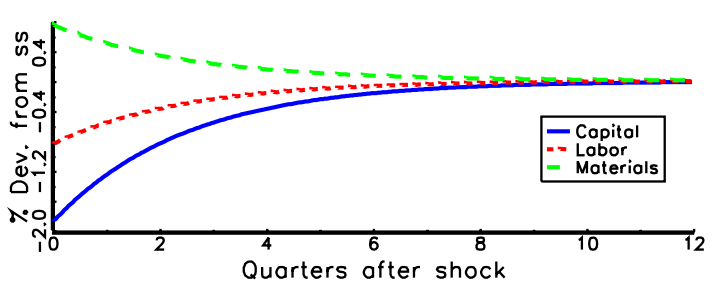

Aggregate price level

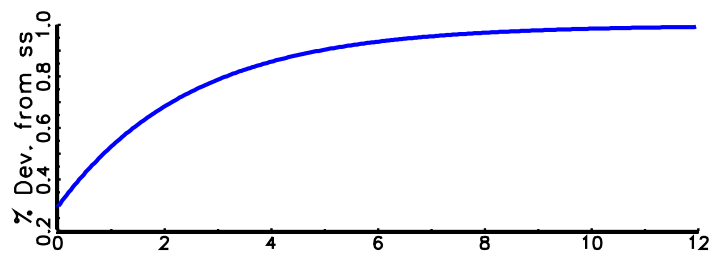

Price: Nondurables

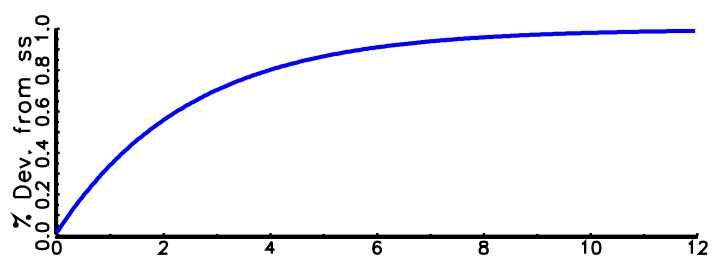

Price: Durables

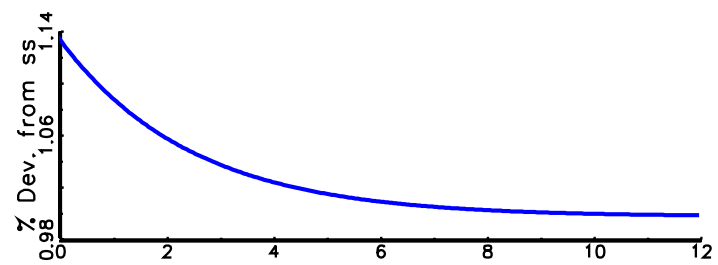

Nominal marginal cost: Nondurables

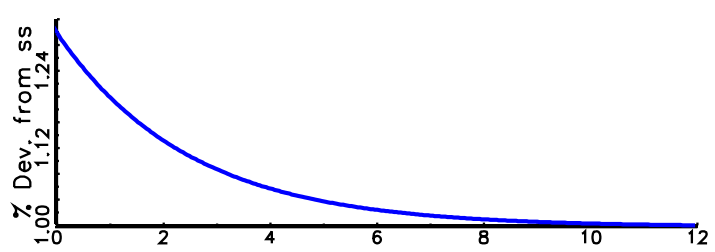

Nominal marginal cost: Durables

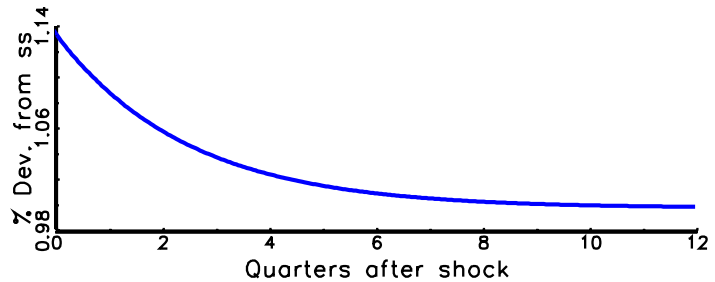

Figure 5: Impulse responses to a 1 percent permanent increase in money supply: Model with materials inputs and perfect labor mobility. 

A. Increased labor mobility
B. Alternative $1-0$ matrix
C. Sticky durables prices
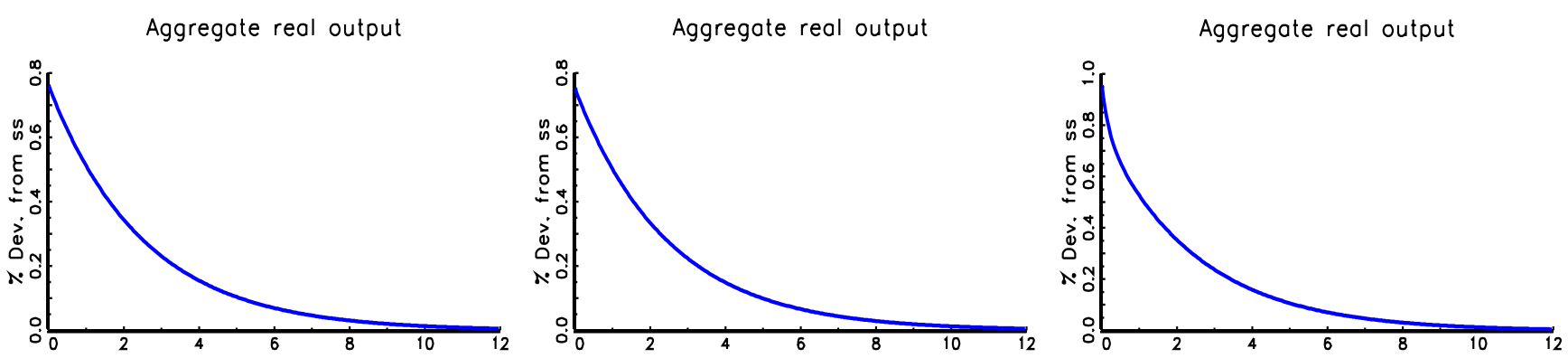

Consumption and production: Nondurables
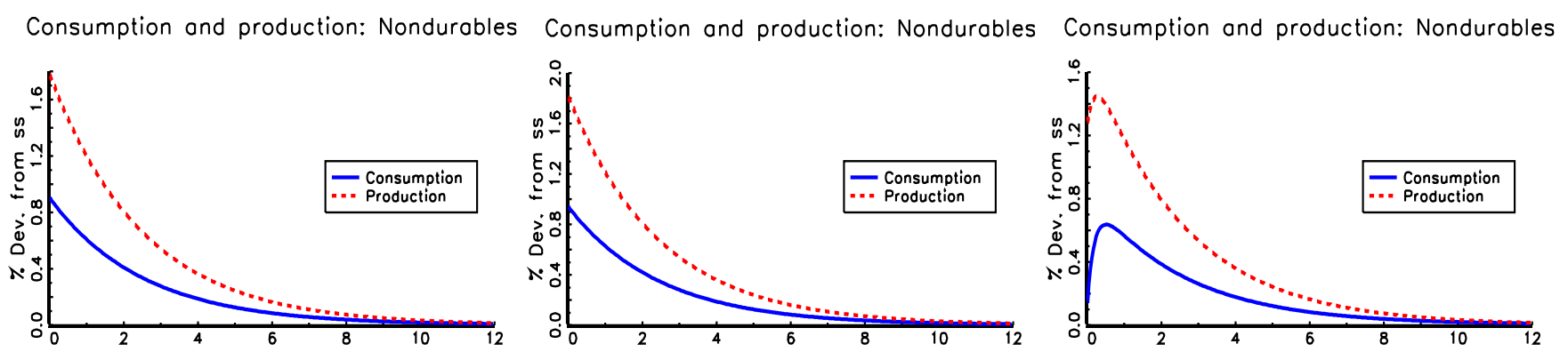

Consumption and production: Durables
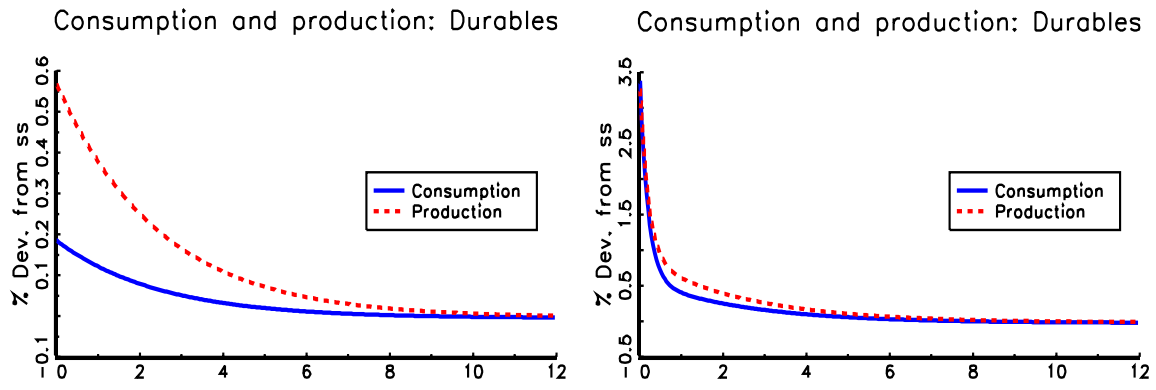

Figure 6: Impulse responses to a 1 percent permanent increase in money supply: Sensitivity analysis. 